\title{
Response of the zooxanthellae of Palythoa caribaeorum (Cnidaria: Zoanthidea) to different environmental conditions in coastal and oceanic ecosystems of the Tropical Atlantic
}

\author{
Gleice S. Santos ${ }^{1}$, Fernanda D. Amaral ${ }^{2}$, Cristiane F. C. Sassi ${ }^{3}$ and Ralf Schwamborn ${ }^{1 *}$
}

\begin{abstract}
The present study tested the hypothesis that endosymbionts of the zoanthid Palythoa caribaeorum show specific responses in cell density, size, and mitotic index (as proxy for cell population growth) under different environmental conditions (water depth, position within the reef and within the colony). Colony fragments were sampled at the nearshore coastal reefs of Porto de Galinhas and at the oceanic St. Peter and St. Paul's archipelago (SPSP), Brazil. At the coastal reefs, zooxanthellae showed higher density on the reef flat (mean: $2.99 \times 10^{6} \mathrm{~cm}^{-2}$ ) than at the back reef (mean: $2.07 \times 10^{6} \mathrm{~cm}^{-2}$ ). Zooxanthellae were larger at the center of the colonies (mean: $10.61 \mu \mathrm{m}$ ) than at the edges (mean: $10.11 \mu \mathrm{m}$ ), where younger polyps were found. At SPSP, zooxanthellae showed smaller cell diameters at $3 \mathrm{~m}$ depth, than at 5-15 m. Cell size increased with depth, thus enhancing the photosynthetic efficiency of colonies in deeper environments. Strategies and adaptations of these endosymbionts to environmental stressors are discussed. Symbiont distribution patterns shown in this study have fundamental implications for the monitoring of the health of tropical reef ecosystems.
\end{abstract}

Keywords: Reef ecosystems, Zoanthids, Symbiosis, Symbiodinium, Benthos ecology, Brazil

\section{Background}

Most corals and zoanthids contain symbiotic dinoflagellates of the genus Symbiodinium (zooxanthellae) in their tissues. These zooxanthellae form symbiotic associations with invertebrates such as foraminiferans, sponges, cnidarians, and mollusks, which use them to obtain photosynthetic energy in the form of carbohydrates. This relationship is vital to many species of cnidarians, considering that the loss of zooxanthellae from host tissues causes the phenomenon known as bleaching, which can cause the host's death $[16,19,20,25,49]$. A plethora of studies on this symbiosis has been conducted with reefbuilding scleractinian corals $[5,18]$. Furthermore, some

\footnotetext{
*Correspondence: rs@ufpe.br

${ }^{1}$ Departamento de Oceanografia, Universidade Federal de Pernambuco,

Av. Professor Moraes Rêgo, 1235, Cidade Universitária, Recife, PE 50670-901, Brazil

Full list of author information is available at the end of the article
}

studies have been conducted on the zooxanthellae of zoanthids [22, 37, 39, 45], which are cnidarians that do not secrete any calcareous exoskeleton, but are often the main structuring organisms of benthic communities in intertidal reef flat and on rocky shores in tropical and temperate regions $[23,31,38,41]$.

Zoanthids are the animals with the highest biomass on many reefs along the Brazilian coast $[9,37,40,42]$, where they play an important role in reef health and stability, protecting reef surfaces from destructive grazers, such as sea urchins [31, 32, 38]. Also, they provide shelter for many animals [33].

Tropical coastal reef ecosystems of Brazil generally present high abundances of zoanthids, even under nearpristine conditions [40], as opposed to Caribbean and Indo-Pacific reefs, where corals often dominate and the dominance of zoanthids and macroalgae is regarded as an indicator of severe human impacts. 
The zoanthid Palythoa caribaeorum (Duchassaing \& Michelotti, 1860) is distributed in coastal and oceanic environments of Brazil [1,31]. It occurs at intertidal and shallow subtidal reef areas. When exposed at low tide on intertidal reef flats, this species secretes a characteristic mucus to prevent desiccation and predation. This species has been the focus of several ecological studies and the target of biochemical research that revealed several active agents and the applicability for toxins of the mucus secreted in huge amounts by these animals, especially with regard to compounds with bactericidal action [17, 24]. There is still little information on Palythoa caribaeorum symbionts. Most studies focus on temperature effects and bleaching [26, 28], seasonality [13], and symbiont diversity [36, 39]. At the oceanic St. Peter and St. Paul's Archipelago, the characteristic vertical zonation of the rocky shore ecosystems includes a $P$. caribaeorum zone, where colonies of this species of up to $15 \mathrm{~m}$ diameter $\left(210 \mathrm{~m}^{2}\right)$ occur [1]. In spite of their dominance on many reef flats, the factors that affect the association between zoanthids and their zooxanthellae are still poorly understood.

To date, the major focus of symbiont research has been on scleractinians corals. Studies on scleractinian corals have shown that key characteristics of symbiont populations, such as cell density, mitotic index, cell diameter, and concentration of photosynthetic pigments, are directly influenced by seasonality, temperature, light, and other factors $[4,10,11,29]$. A single coral colony can exhibit considerable variability in its symbionts, when different areas are observed, as occurs in some coral species [35, 47]. Changes in population parameters of zooxanthellae with depth are well described for scleractinian corals [29, 44, 47]. However, to date, it is still unknown if and how symbiont populations of zoanthids change with depth.

Despite the enormous ecological importance of Palythoa caribaeorum in coastal and oceanic reef environments, there is still little information on the zooxanthellae of this zoanthid species in coastal environments of Brazil and there is no information on zooxanthellae of this species on oceanic islands of the Tropical Atlantic Ocean.

The aim of the present study was to analyze the cell density, size, and mitotic index (as a proxy for cell population growth) of Palythoa caribaeorum zooxanthellae, testing the hypothesis that these key population parameters vary between reef zones (reef flat vs. back reef), within colonies (center vs. edge of the colonies), between sampling areas (coastal vs. oceanic sites), and at different depths.

\section{Methods}

This study was conducted at the nearshore reefs of Porto de Galinhas (PG-8 $8^{\circ} 59^{\prime} 00^{\prime \prime}-8^{\circ} 33^{\prime} 33^{\prime \prime} \mathrm{S} ; 35^{\circ} 00^{\prime} 27^{\prime \prime}-$ $\left.34^{\circ} 59^{\prime} 00^{\prime \prime} \mathrm{W}\right)$, northeastern Brazil, and at the rocky shores of the oceanic St. Peter and St. Paul's Archipelago (SPSP $-00^{\circ} 56^{\prime} \mathrm{N} ; 29^{\circ} 22^{\prime} \mathrm{W}$ ), Brazil. The reefs of PG are adjacent to sandy beaches, being accessible on foot from the shore, and subject to seasonal oscillations in turbidity due to wind-driven turbulence and nutrients from continental runoff. The SPSP archipelago is inhabited only by scientists and navy personnel, being located approximately $1100 \mathrm{~km}$ from the coast, with year-round oligotrophic conditions and extremely transparent waters (Fig. 1).

While the oceanic SPSP archipelago points out of the Middle Atlantic Ridge like a sharp needle and is characterized by steep rocky shores, the PG reefs are located at a flat coastal location, with little if any slope, and extensive intertidal flats, that are bordered by back reef zones and reef fringes, a horizontal zonation that is typical for coastal sandstone reefs in the Tropical Atlantic. The sampling strategy reflects these different geomorphologies: Sampling at the steep rocky shores of SPSP was conducted at different depth strata, while at PG, sampling was performed in different reef zones (intertidal reef flat vs. subtidal back reef walls). Sampling in both areas was conducted in 2008 and 2009, during the dry season (September-February), under conditions of minimum wind and rainfall, and thus maximum transparency in this region.

At the coastal PG reefs, samples were taken from the extensive flat intertidal reef top (reef flat) and from the steep to vertical subtidal back reef walls (back reef), during the period from November 2008 to January 2009. In each zone, 24 fragments were collected from the center and 24 from the edge of P. caribaeorum colonies. Permanently submerged colonies were considered from the back reef walls.

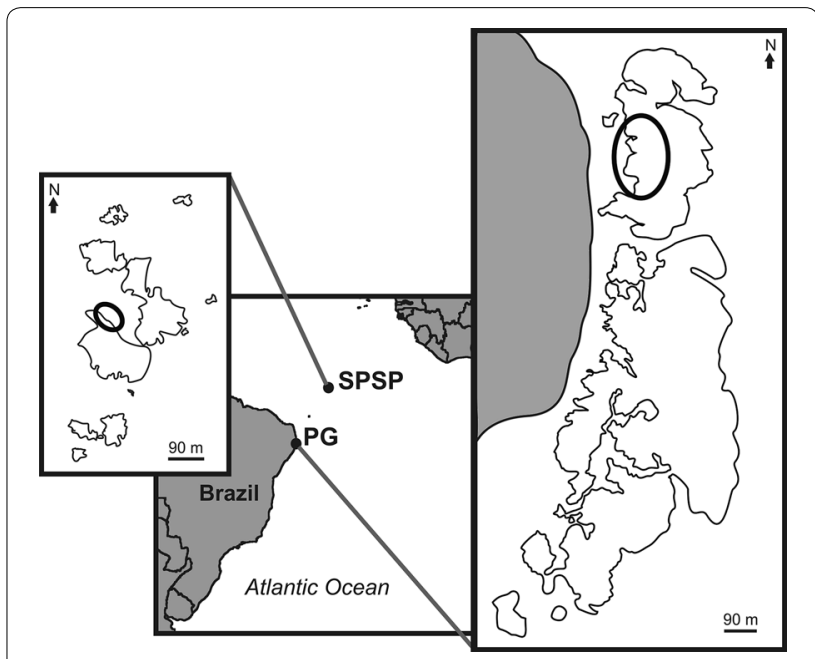

Fig. 1 Map of the study areas: Porto de Galinhas (PG) and St. Peter and St. Paul's Archipelago (SPSP), Brazil. Ellipses indicate sampling sites 
At the oceanic SPSP archipelago, sampling was performed on steep rocky shores in October 2008 and October 2009, with generally five fragments from the center of the colonies at 3, 5, 7, 10, and $15 \mathrm{~m}$ depth in both years.

Samples were removed from the substrate with the aid of a cylindrical sampler of $3.14 \mathrm{~cm}^{2}$ through snorkeling or scuba diving. Forty-two fragments of the colonies were sampled at PG and 43 colonies at SPSP $(4,10,9,10$, and 10 samples at 3, 5, 7, 10, and $15 \mathrm{~m}$ depth, respectively). After sampling, zoanthid fragments were properly labeled and placed in individual plastic jars containing filtered seawater (using Whatman GFC filters) and taken to the laboratory. Subsequently, the samples were ground with the aid of glass rod and a scalpel and homogenized in $25 \mathrm{ml}$ filtered seawater. The homogenate was fixed with 10 drops of 10 \% Lugol. All samples were analyzed in FuchsRosenthal counting chambers. Population density, mitotic index, and cell diameter (ten cells for each colony sample) of the zooxanthellae were determined under a binocular microscope equipped with a micrometer ocular.

All variables were tested for normality using the Kolmogorov-Smirnov test. Since the data were not normally distributed, analyses were performed with Kruskal-Wallis ANOVA and Mann-Whitney $U$ tests [50], to compare population parameters (cell density, cell size, and mitotic index), water depths (3-15 m), reef zones (back reef vs. reef flat), and positions within the colony (edge vs. center). Only samples taken from the centers of the colonies were considered for the comparisons of population parameters between study areas (PG vs. SPSP). All analyses were performed at $\alpha=0.05$.

\section{Results}

Population density, cell size, and mitotic index of $P$. caribaeorum zooxanthellae showed clear responses to different environmental conditions and marked differences between study areas and reef zones.

When comparing different reef zones of the Porto de Galinhas reef, density of zooxanthellae on the reef flat (mean: $2.99 \times 10^{6} \mathrm{~cm}^{-2}$, minimum: $1.16 \times 10^{6} \mathrm{~cm}^{-2}$, maximum: $\left.6.21 \times 10^{6} \mathrm{~cm}^{-2}\right)$ was significantly higher than that at the back reef (mean: $2.07 \times 10^{6} \mathrm{~cm}^{-2}$, minimum: $0.82 \times 10^{6} \mathrm{~cm}^{-2}$, maximum: $4.42 \times 10^{6} \mathrm{~cm}^{-2}$ ) (MannWhitney $U$ test, $p<0.03, n=42$; Fig. 2). Cell diameter and mitotic index did not differ between these reef zones.

When center and edge areas of individual colonies were compared, population density and mitotic index did not show any differences. Symbiont cell size was significantly larger at the center of the colonies (mean diameter: $10.61 \mu \mathrm{m}$, minimum: $9.94 \mu \mathrm{m}$, maximum: $11.55 \mu \mathrm{m}$; Table 1) than that at the edge of the colonies (mean: $10.11 \mu \mathrm{m}$, minimum: $9.17 \mu \mathrm{m}$, maximum: $11.25 \mu \mathrm{m}$, Mann-Whitney $U$ test, $p<0.001, n=42$, Fig. 3).

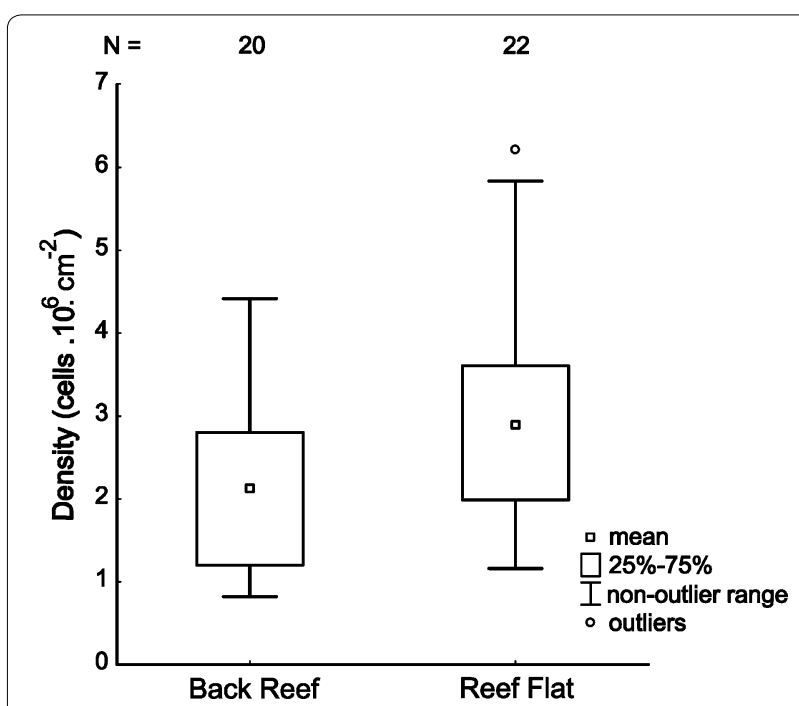

Fig. 2 Population density of $P$. caribaeorum zooxanthellae at different reef sectors (back reef vs. reef flat) at the Porto de Galinhas Reefs, Brazil

At the oceanic SPSP archipelago, population density and mitotic index did not show any differences between depth levels. Cell size showed significant differences between depths, with the formation of similar groups at some depths (Kruskal-Wallis ANOVA, $p<0.006, n=43$, Fig. 3). Smaller cell diameters were found at $3 \mathrm{~m}$ depth $(11.3 \mu \mathrm{m})$ than at $5-15 \mathrm{~m}$ (diameters generally $>12 \mu \mathrm{m}$ ).

When coastal (Porto de Galinhas) and oceanic (SPSP) reefs were compared (centers of the colonies only), population density of zooxanthellae showed significant differences, being higher at the coastal reef (Kruskal-Wallis ANOVA, $p<0.03$; Fig. 4, $n=63$; Table 1). Moreover, the mitotic index was higher and cell diameters were larger at oceanic reefs (Kruskal-Wallis ANOVA, $p<0.001$; $n=63, p<0.001 ; n=63$; Fig. 4; Table 1).

\section{Discussion}

This study contributes to the understanding of the variability in cell population density, size, and growth (assessed the mitotic index) of $P$. caribaeorum zooxanthellae in different reef areas. Furthermore, it contributes to elucidate the depth stratification of symbiont populations at a oceanic rocky shore environment that had not been studied so far.

The higher density of zooxanthellae observed in $P$. caribaeorum colonies located on the intertidal reef flats of Porto de Galinhas, when compared to the lower laying back reef, was unexpected, considering that reef flats have the most hostile environmental conditions, i.e., total exposure of colonies during low tides. These fragile animals are thus submitted to thermal, osmotic, and photic 
Table 1 Mean, minimum ( $\min$ ), maximum (max) values of density, mitotic index, and cell diameter of zooxanthellae of $P$. caribaeorum in Porto de Galinhas (PG) and at St. Peter and St. Paul's Archipelago (SPSP), Brazil

\begin{tabular}{|c|c|c|c|c|c|c|c|c|c|}
\hline & \multicolumn{3}{|c|}{ Density (cells $\times 10^{6} \mathrm{~cm}^{-2}$ ) } & \multicolumn{3}{|c|}{ Mitotic index (\%) } & \multicolumn{3}{|c|}{ Cell diameter $(\mu \mathrm{m})$} \\
\hline & Mean & Min. & Max. & Mean & Min. & Max. & Mean & Min. & Max. \\
\hline \multicolumn{10}{|l|}{$P G$} \\
\hline Reef flat & 2.99 & 1.16 & 6.21 & 3.04 & 0.91 & 6.36 & 10.42 & 9.17 & 11.55 \\
\hline Back reef & 2.07 & 0.82 & 4.42 & 2.96 & 1.36 & 6.1 & 10.29 & 9.5 & 10.75 \\
\hline CC & 2.42 & 0.86 & 6.21 & 2.65 & 0.91 & 4.5 & 10.61 & 9.94 & 11.55 \\
\hline EC & 2.68 & 0.82 & 5.84 & 3.33 & 1.45 & 6.63 & 10.11 & 9.17 & 11.25 \\
\hline \multicolumn{10}{|l|}{$\operatorname{SPSP}(\mathrm{m})$} \\
\hline 3 & 16.85 & 5.97 & 27.79 & 3.62 & 1.33 & 6.73 & 11.25 & 11.06 & 11.38 \\
\hline 5 & 13.39 & 3.7 & 56.49 & 7.28 & 4.3 & 13.05 & 12.31 & 11.69 & 13.06 \\
\hline 7 & 18.4 & 5.81 & 32.36 & 6.43 & 4.79 & 10.34 & 11.98 & 10.93 & 12.81 \\
\hline 10 & 10.36 & 2.25 & 24.64 & 8.12 & 3.45 & 11.47 & 11.72 & 10.87 & 12.44 \\
\hline 15 & 15.97 & 5.16 & 35.59 & 6.16 & 3.33 & 12.11 & 12.44 & 11.37 & 13.63 \\
\hline
\end{tabular}

CC center of the colony, EC edge of the colony
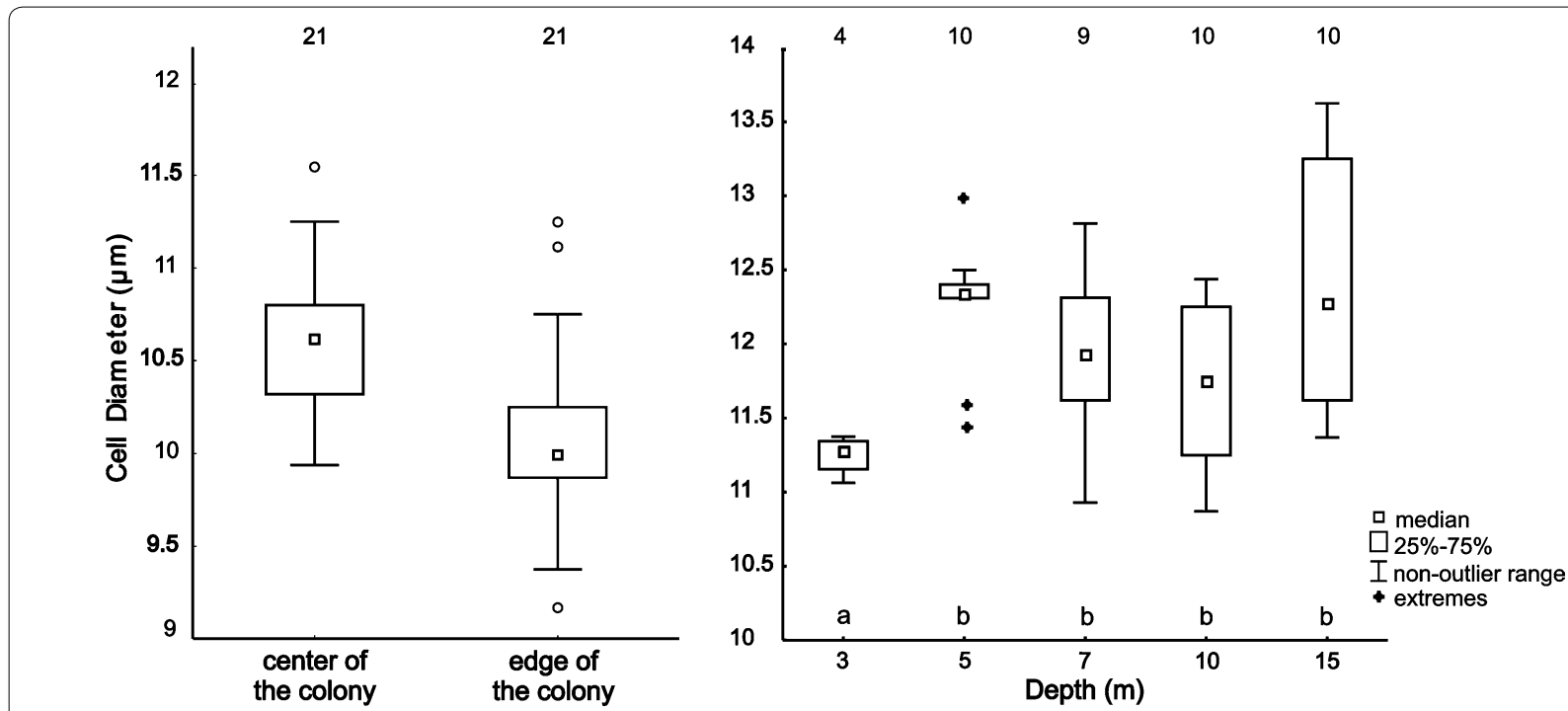

Fig. 3 Cell diameter of P. caribaeorum zooxanthellae $(\mu \mathrm{m})$ in different parts of the colonies of Porto de Galinhas Reefs, and at different depths at St. Peter and St. Paul's Archipelago (SPSP), Brazil

stress factors that do negatively influence symbiosis and could have lead to a lower density on the reef flat $[16,26]$. Higher densities of symbionts on reef flats may be necessary to compensate for the energy needed to cope with multiple stressors in these hostile intertidal areas.

Under hostile environmental conditions, zooxanthellae can be degraded within the tissue of their hosts. This phenomenon can be observed in corals from shallow environments, since colonies that are in shady locations tend to be less degraded and have higher population densities of zooxanthellae as compared to colonies in lightexposed environments [43].
This zoanthid showed a strategy that is similar to many scleractinians, such as Siderastrea stellata, an endemic Brazilian coral species, which features the ability to successfully colonize shallow waters of coastal reefs due to symbiotic zooxanthellae and their adaptation to extreme and variable environments, such as reef flats that are fully exposed during low tides [12].

The maintenance of physiological stability of cnidarians that perform symbiosis with zooxanthellae is directly linked to the population density of symbionts in the host tissue, considering that the latter control the dynamics of zooxanthellae in their tissues [43]. Our 

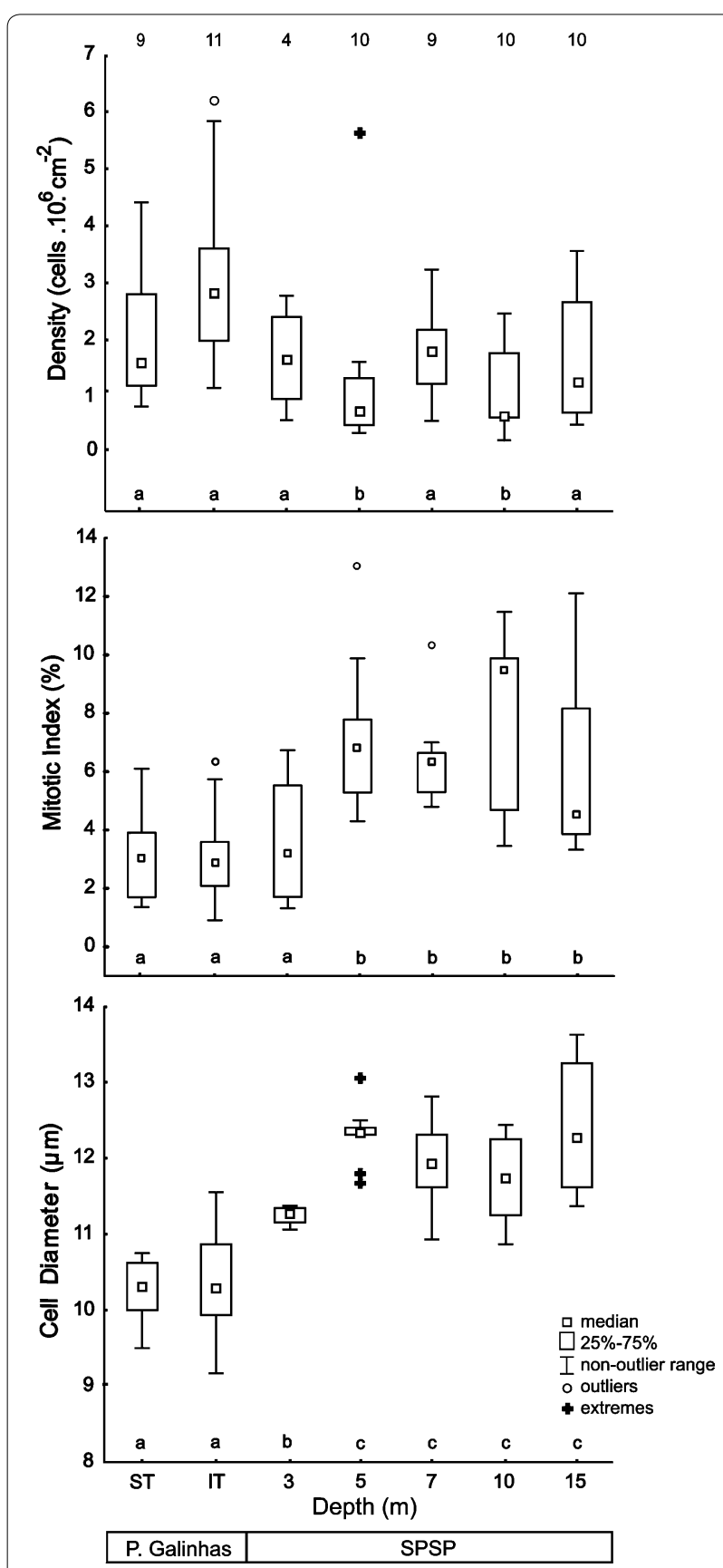

Fig. 4 Comparison of cell population density, mitotic index, and cell diameter of the P. caribaeorum zooxanthellae between the Porto de Galinhas Reefs and St. Peter and St. Paul's Archipelago (SPSP), Brazil. ST subtidal, IT intertidal

results suggest that colonies on the reef flat require more energy in the form of carbohydrates to withstand extreme changes in the environment caused by the total exposure to the air during low tides and would have to compensate this by increasing the amount of zooxanthellae in their tissues.
Increased mucus production is also present in colonies that are in direct contact with sunlight (remaining completely exposed during low tides) as a means to avoid desiccation [41]. Piggot et al. [34] reported a similar strategy for the coral Montastraea annularis, where mucus production was directly influenced by light conditions. Increasing light intensity is thus a factor that significantly influences mucus production and higher density of symbionts in the tissues of scleractinians, similarly to our findings.

There is no information available on the energy required for mucus production in zoanthids. Yet, many studies have shown that the coral species that produce mucus invest large amounts of energy in this process. They may exude up to half of the carbon assimilated by their zooxanthellae as mucus $[14,15,21,46]$. The mucus patches produced by $P$. caribaeorum cover considerable parts of the intertidal reef flats in Brazil. This mucus is one of the most conspicuous characteristics of this species, that is popularly known as "baba-de-boi" ("ox slobber") in Brazil [6, 7, 33, 42]. Obviously, this requires a considerable amount of energy. The energy needed for mucus production could explain the higher density of symbionts found in intertidal reef flats as compared to subtidal colonies.

Furthermore, the density of P. caribaeorum zooxanthellae showed no differences between the edge and center of the colonies, showing that zoanthid symbionts are distributed equally throughout the host tissue. These results validate the sampling methodology used in quantitative studies on the density of zooxanthellae, where any portion of the colonies is being sampled. This may be related to the massive, compact shape of P. caribaeorum colonies, which resemble massive corals. In branching corals, as in Acropora millepora, the population density of symbionts is different in different regions of colonies [35]. The results of this study indicate that the massive shape of zoanthid colonies can be an important factor in the uniform within-colony distribution of symbiont density, as observed in massive corals.

However, cell diameter significantly differed between different regions of $P$. caribaeorum colonies. This could be related to colony growth, as it occurs from the center to the edge [3,23]. Probably, in these marginal areas with younger polyps, a considerable part of symbionts are cells originated from mitotic divisions of mature cells from the center of colonies, given that the cytoplasmic region of daughter cells has a smaller area compared with original cell [27]. The same pattern is observed for branching corals, where larger cells on the top and smaller ones on the base of colonies are observed [47].

In the oceanic SPSP archipelago, depth did not show any influence on the population density of symbionts. 
Conversely, Nir et al. [30] investigated changes in the physiology of Seriatopora hystrix at depths ranging from 10 to $60 \mathrm{~m}$ and observed that symbionts exhibited higher population density and greater amount of photosynthetic pigments at $50 \mathrm{~m}$. The authors concluded that this behavior was due to reduced light intensity with increasing depth, since the increase in the number of symbionts would facilitate the capture of light, making photosynthesis more efficient so as to meet the physiological needs of the host.

Similarly to the present study, Carricart-Ganivet and Beltrán-Torres [8] investigated the population density and chlorophyll $a$ concentration of zooxanthellae in the coral Montastraea cavernosa and observed that these variables did not significantly change between depths ranging from 3 to $18 \mathrm{~m}$. Population density seems not to be influenced by small variations in depth in shallow areas. Only at extreme depths, such as in deep, mesophotic areas (depth $>30 \mathrm{~m}$ ), cell density of coral zooxanthellae seems to increase to compensate for the extreme light deficiency, as shown in Nir et al. [30]. Since the present study was conducted well within the euphotic zone (maximum depth: $15 \mathrm{~m}$ ), no changes in population density were observed.

On the other hand, cell diameter of $P$. caribaeorum symbionts showed a significant increase with depth. Our results corroborate the work of Wilkerson et al. [47], who studied the cell diameter of nine species of scleractinian corals in Jamaica at four different depths and observed that the cell diameter of zooxanthellae also increased with depth. Similarly, Winters et al. [48] studied Stylophora pistillata coral (Esper 1797) at 2 and $30 \mathrm{~m}$ deep and also found that this variable is directly influenced by local depth.

Therefore, symbionts probably compensate for decreasing light intensity by increasing their cell surface (i.e., cell diameter), as to obtain space for a greater amount of chloroplasts in their cytoplasm, thereby providing better light capture and making more efficient photosynthesis. Due to increased cell diameter in deeper regions, colonies in these environments probably do not have the need to increase the cell density of symbionts in their tissues.

Baseline data on zooxanthellae of cnidarians are essential for the understanding of current and future variations of tropical coastal and oceanic ecosystems, including extreme events, such as bleaching $[2,16,26,28]$. The symbiont distribution patterns shown in this study have fundamental implications for future continuous monitoring programs of the health of tropical reef ecosystems.

\section{Authors' contributions}

GSS did the fieldwork, collected data, analysed data and wrote the manuscript. FDA designed the study and wrote the manuscript. CFC analysed data and wrote the manuscript. RS analysed data and wrote the manuscript. All authors read and approved the final manuscript.

\begin{abstract}
Author details
${ }^{1}$ Departamento de Oceanografia, Universidade Federal de Pernambuco, Av. Professor Moraes Rêgo, 1235, Cidade Universitária, Recife, PE 50670-901, Brazil. 2 Departamento de Biologia, Universidade Federal Rural de Pernambuco, Rua Dom Manoel de Medeiros, s/n, Dois Irmãos, Recife, PE 52171-900, Brazil. ${ }^{3}$ Departamento de Sistemática e Ecologia, Universidade Federal da Paraíba, Campus I - Cidade Universitária, s/n, João Pessoa, PB 58059-900, Brazil.
\end{abstract}

\section{Acknowledgements}

The authors would like to thank the Brazilian National Research Council (CNPq) for financial support granted to the Project "Diagnosis of marine invertebrate fauna of St. Peter and St. Paul's Archipelago: updates and new approaches" (CNPq No. 558448/2005-4). We would like to thank the Brazilian Navy for logistic support for the expeditions to SPSP. We would like to thank Michelle Santos and Christinne Eloy for their valuable suggestions and Manuel Flores and Fernando Feitosa for their support during laboratory work. The authors thank the anonymous reviewers for their comments, which helped to substantially improve the manuscript.

\section{Competing interests}

The authors declare that they have no competing interests.

Received: 10 June 2015 Accepted: 24 November 2015

Published online: 20 April 2016

\section{References}

1. Amaral FMD, Rocha C, Farrapeira CMR, Alves, Pinto SL, Lira SMA, Lima KKM, Ramos CAC, Santos ECL, Moura JR, Oliveira DAS, Verçosa MM, Melo AVOM, Oliveira APA, Gonçalves EF. Distribuição espacial de invertebrados bentônicos infralitorais. In: Viana DL, Hazin FHV, Souza MAC, editors. O Arquipélago de São Pedro e São Paulo: 10 anos de Estação Científica. Brasília: SECIRM; 2009. p. 148-56

2. Baker AC. Ecosystems: reef corals bleach to survive change. Nature. 2001:411:765-6. doi:10.1038/35081151.

3. Bastidas C, Bone D. Competitive strategies between Palythoa caribaeorum and Zoanthus sociatus (Cnidaria: Anthozoa) at a reef flat environment in Venezuela. Bull Mar Sci. 1996;59(3):543-55.

4. Biscéré T, Rodolfo-Metalpa R, Lorrain A, Chauvaud L, Thébault J, Clavier J, Houlbrèque $F$. Responses of two Scleractinian corals to cobalt pollution and ocean acidification. PLoS One. 2015;10(4):1-18. doi:10.1371/journal. pone.0122898.

5. Bongaerts PM, Bridge EM, Ridgway TCL, Vermeulen T, Englebert F, Webster N, Jody M, Hoegh-Guldberg O. Symbiodinium diversity in mesophotic coral communities on the Great Barrier Reef: a first assessment. Mar Ecol Prog Ser. 2011;439:117-26. doi:10.3354/meps09315.

6. Campos FF, Garcia JE, Luna-Finkler CL, Davolos CC, Lemos MVF, Pérez CD. Alcanivorax dieselolei, an alkane-degrading bacterium associated with the mucus of the zoanthid Palythoa caribaeorum (Cnidaria, Anthozoa). Braz J Biol. 2015;75(2):431-4. doi:10.1590/1519-6984.16113.

7. Carlos C, Torres TT, Ottoboni LMM. Bacterial communities and speciesspecific associations with the mucus of Brazilian coral species. Sci Rep. 2013:3:1624. doi:10.1038/srep01624.

8. Carricart-Ganivet JP, Beltrán-Torres AV. Zooxanthellae and chlorophylla $a$ responses in the scleractinian coral Montastrea cavernosa at Triangulos W Reef, Campeche Bank, Mexico. Rev Biol Trop. 1993;41(3):491-4.

9. Costa OS Jr, Attrill MJ, Pedrini AG, De-Paula JC. Benthic macroalgal distribution in coastal and offshore reefs at Porto Seguro Bay, Brazilian Discovery Coast. In: Proceedings of the 9th international coral reef symposium. International Society for Reef Studies, Indonesia, 23-27; 2001.

10. Costa CF, Sassi R Jr, Amaral FD. Population and photosynthetic pigment content in symbiotic dinoflagellates in the Brazilian scleractinian coral Montastrea cavernosa (Linnaeus, 1767). Braz J Oceanogr. 2004;52(2):93-9. doi:10.1590/S1679-87592004000200001

11. Costa CF, Sassi R, Amaral FD. Annual cycle of symbiotic dinoflagellates from three species of scleractinian corals from coastal reefs of northeastern Brazil. Coral Reefs. 2005;24:191-3. doi:10.1007/ s00338-004-0446-2. 
12. Costa CF, Sassi R, Gorlach-Lira K. Zooxanthellae genotypes in the coral Siderastrea stellata from coastal reefs in northeastern Brazil. J Exp Mar Biol Ecol. 2008;367:149-52. doi:10.1016/j.jembe.2008.09.012.

13. Costa CF, Sassi R, Gorlach-Lira K, Lajeunesse TC, Fitt WK. Seasonal changes in zooxanthellae harbored by zoanthids (Cnidaria, Zoanthidea) from coastal reefs in northeastern Brazil. Panam J Aquat Sci. 2013;8(4):253-64.

14. Crossland C, Barnes D, Borowitzka M. Diurnal lipid and mucus production in the staghorn coral Acropora acuminata. Mar Biol. 1980;60:81-90. doi:10.1007/BF00389151.

15. Davies PS. The role of Zooxanthellae in the nutritional energy requirements of Pocillopora eydouxi. Coral Reefs. 1984;2:181-6. doi:10.1007/ BF00263571.

16. Douglas AE. Coral bleaching — how and why? Mar Pollut Bull. 2003:46:385-92. doi:10.1016/S0025-326X(03)00037-7.

17. Garcia-Castineiras S, White Jl, Rodriguez LD, Toro-Goyco E. $\left(\mathrm{Na}^{+}+\mathrm{K}^{+}\right)$ ATPase inhibition by Palythoa extracts: chemical nature of the inhibitor and kinetics of inhibition. Biochem Pharmacol. 1977;26(7):589-94. doi:10.1016/0006-2952(77)90029-6.

18. Gittins JR, D'Angelo C, Oswald F, Edwards RJ, Wiedenmann J. Fluorescent protein-mediated colour polymorphism in reef corals: multicopy genes extend the adaptation/acclimatization potential to variable light environments. Mol Ecol. 2015;24:453-65. doi:10.1111/mec.13041.

19. Glynn PW. Coral reef bleaching: ecological perspectives. Coral Reefs. 1993;12:1-17. doi:10.1007/BF00303779.

20. Gordon BR, Leggat W. Symbiodinium - invertebrate symbioses and the role of metabolomics. Mar Drugs. 2010;8:2546-68. doi:10.3390/ md8102546.

21. Goreau TF, Goreau NI, Goreau TJ. Corals and coral reefs. Sci Am. 1979;241(2):124-35.

22. Grant A, Trompf K, Seung D, Nivison-Smith L, Bowcock H, Kresse H, Holmes S, Radford J, Morrow P. Sub-cellular damage by copper in the cnidarian Zoanthus robustus. Comp Biochem Phys C. 2010;152:256-62. doi:10.1016/j.cbpc.2010.04.013.

23. Herberts C. Ordre des Zoanthaires. In: Grasse PP, Doumenc D, editors. Traite de Zoologie, Anatomie, Systematique, Biologie. Paris: Elsevier Masson; 1987. p. 783-810.

24. Hoffmann K, Hermanns-Clausen M, Buhl C, Markus S, Buchler MW, Schemmer P, Mebssilke D, Kauferstein C. A case of palytoxin poisoning due to contact with zoanthid corals through a skin injury. Toxicon. 2008;51(8):1535-7. doi:10.1016/j.toxicon.2008.03.009.

25. Jarms G, Morandini AC, Silveira FL. Cultivation of polyps and medusae of Coronatae (Cnidaria, Scyphozoa) with a brief review of important characters. Helgol Mar Res. 2002;56:203-10. doi:10.1007/s10152-002-0113-3.

26. Kemp DW, Clayton BC, Todd CL, Brooks WR. A comparison of thermal bleaching responses of the zoanthid Palythoa caribaeorum from three geographically different regions in south Florida. J Exp Mar Biol Ecol. 2006;335(2):266-76. doi:10.1016/j.jembe.2006.03.017.

27. Lee RE. Phycology. New York: Cambridge University Press; 2008.

28. Lesser MP, Stochaj WR, Tapley DW, Shick JM. Bleaching in coral reef anthozoans: effects of irradiance, ultraviolet radiation, and temperature on the activities of protective enzymes against active oxygen. Coral Reefs. 1990;8(4):225-32. doi:10.1007/BF00265015.

29. Lesser MP, Slattery M, Stat M, Ojimi M, Gates RD, Grottoli A. Photoacclimatization by the coral Montastraea cavernosa in the mesophotic zone: light, food, and genetics. Ecology. 2010;91(4):990-1003. doi:10.1890/09-0313.1.

30. Nir O, Gruber DF, Einbinder S, Kark S, Tchernov D. Changes in scleractinian coral Seriatopora hystrix morphology and its endocellular Symbiodinium characteristics along a bathymetric gradient from shallow to mesophotic reef. Coral Reefs. 2011;30(4):1089-100. doi:10.1007/s00338-011-0801-z.

31. Oigman-Pszczol SS, Figueiredo MAO, Creed JC. Distribution of benthic communities on the tropical rocky subtidal of Armação dos Búzios, Southeastern Brazil. Mar Ecol. 2004;25(3):173-90. doi:10.1111/j.1439-0485.2004.00018.x.
32. O'Leary JK, McClanahan TR. Trophic cascades result in large-scale coralline algae loss through differential grazer effects. Ecology. 2010;91(12):3584. doi:10.1890/09-2059.1.

33. Pèrez CD, Vila-Nova DA, Santos AM. Associated community with the zoanthid Palythoa caribaeorum (Duchassaing \& Michelotti, 1860) (Cnidaria, Anthozoa) from littoral of Pernambuco, Brazil. Hydrobiologia. 2005:548(1):207-15. doi:10.1007/s10750-005-5441-2.

34. Piggot AM, Fouke BW, Sivaguru M, Sanford RA, Gaskins HR. Change in zooxanthellae and mucocyte tissue density as an adaptive response to environmental stress by the coral Montastraea annularis. Mar Biol. 2009:156:2379-89. doi:10.1007/s00227-009-1267-1.

35. Pillay RM, Willis $B$, Terashima $\mathrm{H}$. Trends in the density of zooxanthellae in Acropora millepora (Ehrenberg, 1834) at the Palm Island Group, Great Barrier Reef, Australia. Symbiosis. 2005;38:209-26.

36. Rabelo EF, Rocha LL, Colares GB, Bomfim TA, Nogueira VLR, Katzenberger M, Matthews-Cascon H, Melo VMM. Symbiodinium diversity associated with zoanthids (Cnidaria: Hexacorallia) in Northeastern Brazil. Symbiosis. 2014;64:105-13. doi:10.1007/s13199-014-0308-9.

37. Rabelo EF, Soares MO, Bezerra LEA, Matthews-Cascon H. Distribution pattern of zoanthids (Cnidaria: Zoantharia) on a tropical reef. Mar Biol Res. 2015;11(6):584-92. doi:10.1080/17451000.2014.962542.

38. Reimer JD, Hirose M, Yanagi K, Sinniger F. Marine invertebrate diversity in the oceanic Ogasawara Islands: a molecular examination of zoanthids (Anthozoa: Hexacorallia) and their Symbiodinium (Dinophyceae). Syst Biodivers. 2011;9(2):133-43. doi:10.1080/14772000.2011.569034.

39. Reimer JD, Lorion J, Irei Y, Hoeksema BW, Wirtz P. Ascension Island shallow-water Zoantharia (Hexacorallia: Cnidaria) and their zooxanthellae. J Mar Biol Assoc UK. 2014; doi:10.1017/S0025315414000654.

40. Santos GS, Burgos DC, Lira SMA, Schwamborn R. The impact of trampling on reef Macrobenthos in Northeastern Brazil: how effective are current conservation strategies? Environ Manag. 2015;56:847-58. doi:10.1007/ s00267-015-0552-7.

41. Sebens KP. Intertidal distribution of zoanthids on the Caribbean coast of Panama: effects of predation and desiccation. Bull Mar Sci. 1982;32(1):316-35

42. Silva JF, Gomes PB, Santana EC, Silva JM, Lima EP, Santos AMM, Pérez CD. Growth of the tropical zoanthid Palythoa caribaeorum (Cnidaria: Anthozoa) on reefs in northeastern Brazil. An Acad Bras Cienc. 2015;87(2):98596. doi:10.1590/0001-3765201520140475.

43. Titlyanov EA, Titlyanova TV, Leletkin VA, Tsukahara J, Woesik RV, Yamazato K. Degradation of zooxanthellae and regulation of their density in hermatypic corals. Mar Ecol Prog Ser. 1996;139:167-78.

44. Toller WW, Rowan R, Knowlton N. Zooxanthellae of the Montastraea annularis species complex: patterns of distribution of four taxa of Symbiodinium on different reefs and across depths. Biol Bull. 2001;201(3):348-59.

45. Trench RK. Nutritional potentials in Zoanthus sociathus (Coelenterata, Anthozoa). Helgol Mar Res. 1974;26(2):174-216. doi:10.1007/BF01611382.

46. Wild C, Huettel M, Klueter A, Kremb SG, Rasheed MYM, BoB Jørgensen. Coral mucus functions as an energy carrier and particle trap in the reef ecosystem. Nature. 2004;428:66-70. doi:10.1038/nature02344.

47. Wilkerson FP, Kobayashi D, Muscatine L. Mitotic index and size of symbiotic algae in Caribbean reef corals. Coral Reefs. 1988;7(1):29-36. doi:10.1007/BF00301979.

48. Winters G, Beer S, Zvi BB, Brickner I, Loya Y. Spatial and temporal photoacclimation of Stylophora pistillata: zooxanthella size, pigmentation, location and clade. Mar Ecol Prog Ser. 2009;384:107-19. doi:10.3354/meps08036.

49. Yellowlees D, Rees TA, Leggat W. Metabolic interactions between algal symbionts and invertebrate hosts. Plant Cell Environ. 2008;31(5):679-94. doi:10.1111/j.1365-3040.2008.01802.x

50. Zar JH. Biostatistical analysis. 3rd ed. Upper Saddle River: Prentice Hall; 1996. 